\title{
The practical barriers to kickstarting the innovation and investment in the sphere of construction in Russian Federation
}

\author{
Anatoly Asaul ${ }^{1 *[0000-0002-7415-4737]}$, Maksim Asaul ${ }^{20000-0003-3040-5765]}$, Irina Drozdova ${ }^{1}$, Yuri \\ Levin $^{3}$, and Ekaterina Trushkovskaya ${ }^{1}$ \\ ${ }^{1}$ Saint-Petersburg State University of Architecture and Civil Engineering (SPSUACE), Saint \\ Petersburg, Russia \\ ${ }^{2}$ Saint-Petersburg State University of Civil Aviation, 196210 Saint-Petersburg, Russia \\ ${ }^{3}$ Moscow State Institute of International Relations (MGIMO-University), Moscow, Russia
}

\begin{abstract}
We have identified the main issues in introducing innovation into a construction project. The solution is realized through the study of both objective and subjective obstacles to the introduction of the innovative technologies in the investment - construction cycle, which is treated as a single process, because the economic effects of innovation can be evaluated only within the full life cycle of a building. We created a highly interconnected financial model of the compounding effects of innovation in the construction industry. We present the Russian construction market's challenges and feedback loops in innovation by using graph theory and complex analysis. The article presents the method developed in the scientific school «Methodological problems of the economic effectiveness of regional construction clusters as a self-ordering system» that shows the algorithmic consistency and transparency of evaluating the effectiveness of the innovations.

The described method can be used in a large array of scientific and theoretical tasks: from the replication of the method to other types of economic activity to the synthesis of methods and models for identifying key areas of innovation activity. It can also be used to build a method for assessing the innovative potential of a project.
\end{abstract}

Keywords: innovation, production cycle, financial model, economic outcomes, synthesized graph.

\section{Introduction}

The construction market in Russia uses $25 \div 35 \%$ of the domestic steel manufacturing capacity, up to $35 \%$ of Aluminum, $25 \%$ of plastics and up to $30 \%$ of wood [1]. This makes the construction sphere a number one domestic consumer of the Russian raw materials. The competitiveness/monopolization index of the Russian construction market is worse than that of the comparable EU markets [2], which in turn affects the cost of

\footnotetext{
*Corresponding author: asaul@yandex.ru
} 
construction (10.3 euro for $1 \mathrm{sqm}$ ) [3]. We examine the cost of land and its infrastructure and innovation in determining the cost of construction [4].

In Russia, the main cost-defining factors of construction are the institutional inefficiencies - transactions are so expensive that they take around $25 \%$ of the overall cost [5].

What the EU and Russia have in common is the conservatism of their construction industries. Both in Russia and in the EU, construction is a «laggard industry». R\&D spending in construction in the EU is worth $0.3-0.5 \%$ of the overall revenue [6]. For comparison, an industry that's widely seen as a low-tech in the EU, the natural resource extraction, has R\&D spending of around $4 \%$. [7]. Russian R\&D spending in construction is $0.47 \%$ of revenue - a fairly European number.

Analysis of the Russian scientific literature $[8,9,10]$ shows a fundamental restructuring [11] of the production pipelines in construction - with the IT (informational technology) approaches being the main inspiration $[12,13]$.

These modernized pipelines require a new kind of administrative [14] and managerial approaches $[15,16]$.

Purpose of the research:

To identify the main issues preventing the introduction of innovations into the investment and construction project; to show that the relationship between the results of innovation and the economic parameters of the investment and construction life cycle of the project leads to multi-economic effects.

\section{Methods}

\subsection{Investment-oriented planning}

This method is structured like this:

- First, a qualitative comparison of the potential result between the innovative and the conservative/basic scenarios is made.

- A model of the project's long-term (sequentially separated) economic impacts is calculated. At this stage there's a good estimate of the costs and time required to do the project.

- The comparison between the innovative and conservative scenarios becomes quantitative.

There's 7 iterations:

1. A calculation of the cost of the non-innovative components of the project.

2. A maximally detailed and precise description of the innovative component of the project. It's always paired with an estimate of the impacts of this innovation.

3. An estimate of the cost of innovation.

4. Calculating the NPV (net present value) of the project. Answering how the innovation will affect it.

5. Answering how the innovation will affect the schedule of the project.

6. Writing the final investment planning documents.

7. Writing the final comparison between the basic and the innovative scenarios.

\subsection{Graph optimizing method}

The aim of this method is to figure out the relationships between the different phases in the production cycle. A graph is a visualization tool - like a «mind map» or a block scheme. The nodes (vertexes) of the graph are the economic parameters, work processes and technological results of the production cycle. The most relevant («heaviest», most 
connected) bonds (edges) between the nodes of the graph pinpoint to the most crucial opportunities for investment.

\section{Results and discussion}

There's around 20 various criteria for determining an attractiveness of investment, but when it comes to the methods, there were only the two methods described above. In 2015, we, the authors of this article, developed a new, combined and updated method. It's an achievement of the journal club called «Methodological problems of the economic effectiveness of regional construction clusters as a self-ordering system». This method had been proven to be extremely effective and transparent (Table 1).

Table 1. Stages of the production cycle.

\begin{tabular}{|c|c|c|}
\hline $\begin{array}{l}\text { Stages of the } \\
\text { cycle }\end{array}$ & What to do & Results \\
\hline 1 & 2 & 3 \\
\hline \multicolumn{3}{|c|}{ Stage A. Proving the value hypothesis. } \\
\hline $\begin{array}{l}\text { Choosing the } \\
\text { intentions } \\
\text { investment. }\end{array}$ & $\begin{array}{l}\text { Develop a functional conception of the } \\
\text { project. Set a marketing strategy. Choose } \\
\text { the investment route. }\end{array}$ & $\begin{array}{l}\text { Business plan for the } \\
\text { investors. }\end{array}$ \\
\hline $\begin{array}{l}\text { Preparation } \\
\text { pre-production. }\end{array}$ & $\begin{array}{l}\text { Answer the «why?» questions. Get a license } \\
\text { for this project. Find the right place for it. } \\
\text { Write an «architectural planning task». }\end{array}$ & $\begin{array}{l}\text { The first functional } \\
\text { and legal documents: } \\
\text { «a note for the } \\
\text { investor», a landmark } \\
\text { for construction, an } \\
\text { «architectural planning } \\
\text { task». }\end{array}$ \\
\hline \multicolumn{3}{|c|}{ Stage B. Project research. } \\
\hline $\begin{array}{l}\text { Engineering } \\
\text { research. }\end{array}$ & $\begin{array}{l}\text { Research the land properties. Geodesic, } \\
\text { geological, hydrometeorological, and } \\
\text { ecological research of the ground building } \\
\text { materials and the underground water } \\
\text { sources. }\end{array}$ & $\begin{array}{l}\text { Research documents } \\
\text { made in accordance } \\
\text { with the government } \\
\text { regulation called SNiP } \\
11-02-96 \text {. }\end{array}$ \\
\hline Design. & $\begin{array}{l}\text { Write the updated functional documents - } \\
\text { both about the product design and about the } \\
\text { costs of manufacturing. A general plan, the } \\
\text { melioration component, the farming } \\
\text { component, the standards for the } \\
\text { organizational processes, the description of } \\
\text { the effect of the surrounding ecosystem on } \\
\text { the object (and vice versa), the description } \\
\text { of disaster-proofing. A legal approval for } \\
\text { joining the external engineering networks. }\end{array}$ & $\begin{array}{l}\text { A «technical task» } \\
\text { note for the project, } \\
\text { the experts' } \\
\text { conclusion, the } \\
\text { approval of the project } \\
\text { and a set of the } \\
\text { technical } \\
\text { documentation (SNiP } \\
\text { 11-01-95) }\end{array}$ \\
\hline \multicolumn{3}{|c|}{ Stage C. Construction. } \\
\hline $\begin{array}{l}\text { Installation and } \\
\text { construction } \\
\text { works. }\end{array}$ & $\begin{array}{l}\text { Choose the main contractor, sign the } \\
\text { contract, (after a tendering among the } \\
\text { contractors, sub-contractors and the } \\
\text { importers). Set a standard process for } \\
\text { quality assurance (QA), schedule assurance } \\
\text { and technical assurance. Budget assurance. }\end{array}$ & $\begin{array}{l}\text { A real state object } \\
\text { that's ready for use. }\end{array}$ \\
\hline
\end{tabular}




\begin{tabular}{|c|l|c|}
\hline \multicolumn{1}{|c|}{$\begin{array}{c}\text { Stages of the } \\
\text { cycle }\end{array}$} & \multicolumn{1}{|c|}{ What to do } & Results \\
\hline 1 & \multicolumn{1}{|c|}{2} & 3 \\
\hline & $\begin{array}{l}\text { Testing and commissioning. Preparing the } \\
\text { object for the use. }\end{array}$ & \\
\hline Stage D. Exploitation. \\
\hline $\begin{array}{l}\text { Maintenance of } \\
\text { real estate }\end{array}$ & $\begin{array}{l}\text { Secure the legal rights. Sell or rent. } \\
\text { Maintenance assurance (including the } \\
\text { engineering infrastructure). }\end{array}$ & Profit, ROI. \\
\hline
\end{tabular}

NPV (net present value) is the number one criteria. Let's look at a positive cashflow $(C F)$ and negative cashflow $(I C)$ in time:

$$
N P V=\sum^{T} \frac{C F_{t}}{(1+i)^{t}}-\sum^{T} \frac{I C_{t}}{(1+i)^{t}}
$$

where:

$N P V \quad-$ net present value;

$i \quad-$ discount rate;

$T \quad-$ the time that the production cycle takes, from start to finish;

CF - positive cashflow;

IC - negative cashflow;

Here's an equation for the components of cashflows:

$$
N P V=\sum_{i=1}^{n} \frac{(Q \times p)_{t}}{(1+i)^{t}}-\sum_{i=1}^{n} \frac{(C P+C M+C T+C C)_{t}}{(1+i)^{t}}
$$

where:

$$
\begin{array}{ll}
Q & \text { - the sales volume of ready-to-use construction products (rubles for a sq } \mathrm{m} \text { ); } \\
P & \text { - the sell price of ready-to-use construction products (rubles for a sq m); } \\
C P & \text { - labor costs (including tax); } \\
C M & \text { - prime costs of resources; } \\
C T & \text { - prime costs of equipment; } \\
C C & \text { - overhead costs. }
\end{array}
$$

\begin{tabular}{|c|c|c|c|}
\hline Code & Type of innovation & Economic impact & Variable \\
\hline 1 & 2 & 3 & 4 \\
\hline Proc. A & $\begin{array}{l}\text { Geoinformational } \\
\text { systems of scanning. }\end{array}$ & $\begin{array}{l}\text { Shortening of the } \\
\text { «proving the value } \\
\text { hypothesis» stage. }\end{array}$ & $\Delta t_{A}$ \\
\hline Tech. B1 & \multirow{2}{*}{$\begin{array}{l}\text { Equipment for project } \\
\text { research. New } \\
\text { process/method } \\
\text { thinking. } \\
\text { GPS/GLONASS, CAD- } \\
\text { based systems, E-Plan, } \\
\text { 3D design and printing. }\end{array}$} & $\begin{array}{l}\text { Shortening of the «project } \\
\text { research» stage. }\end{array}$ & $\Delta t_{B}$ \\
\hline Tech. B2 & & $\begin{array}{l}\text { Raising the quality of } \\
\text { R\&D, shortening of the } \\
\text { «construction» stage. }\end{array}$ & $\Delta t_{c l}$ \\
\hline Org. B & Optimization of & Less overhead. & $\Delta C C_{B}$ \\
\hline
\end{tabular}

The balance and distribution of these expenses is shown in the Table 2 (Table 2, column 2).

Table 2. Decomposition of the economic impacts of innovation during the production cycle. 


\begin{tabular}{|c|c|c|c|}
\hline & overhead costs in R\&D. & & \\
\hline Prod. C1 & \multirow{2}{*}{$\begin{array}{l}\text { The cutting edge } \\
\text { building materials and } \\
\text { constructions. }\end{array}$} & Less overhead. & $\triangle C M$ \\
\hline Prod. C2 & & $\begin{array}{l}\text { Raising the quality of } \\
\text { products, which helps } \\
\text { maintaining and raising } \\
\text { the price }\end{array}$ & $\Delta p$ \\
\hline Proc. $\mathrm{C} 1$ & \multirow{4}{*}{$\begin{array}{l}\text { Installation and } \\
\text { construction know- } \\
\text { hows. }\end{array}$} & $\begin{array}{l}\text { Shortening of the } \\
\text { «construction» stage. }\end{array}$ & $\Delta t_{c 2}$ \\
\hline Proc. C2 & & $\begin{array}{l}\text { Labor that's optimized in } \\
\text { cost. }\end{array}$ & $\triangle C P_{c}$ \\
\hline Proc. C3 & & $\begin{array}{l}\text { A lesser expenditure on } \\
\text { equipment. }\end{array}$ & $\triangle C T$ \\
\hline Proc. C4 & & $\begin{array}{l}\text { A lesser expenditure on } \\
\text { materials. }\end{array}$ & $\triangle C M$ \\
\hline Org. C & $\begin{array}{l}\text { New process/method } \\
\text { thinking in } \\
\text { management. }\end{array}$ & Less overhead. & $\Delta C C_{c}$ \\
\hline Mar. D & Marketing. & $\begin{array}{l}\text { Less time required for a } \\
\text { sale. }\end{array}$ & $\Delta t_{M}$ \\
\hline
\end{tabular}

The aforementioned parameters $(2$ - of the positive cashflow, 4 - of the negative cashflow, and the length of the cycle $-T$ ) are essential to the results of design and process thinking in construction, such as:

1. Upping the productivity rate of construction;

2. Getting to a better labor-output ratio;

3. Getting to a better energy-output ratio;

4. Getting to a better material-output ratio;

5. Getting to a better capital-output ratio;

6. Shortening the time of technological procedures;

7. Raising the quality of product;

8. Getting to a more ecologically-conscious approach to construction;

9. Raising the variety of products;

10. Maintaining the distribution networks;

11. Raising the flexibility of production;

12. Better labor conditions;

13. A more time-efficient contracting;

14. A drastically better informational architecture allows for a clearer, more actionable/functional communication;

15. A more efficient maintenance of real estate.

Visualization of the production cycle is shown above (Equations 1,2). Results of new process/method thinking are shown below (Fig. 1). Interpretation of the results are shown in Table 2.

Our research had shown a clear compounding effect, synergy, multiplication of the good outcomes, a positive feedback loop when it comes to innovation in construction. Better labor conditions mean a more efficient spending on salaries, less overhead and less time to build (driven by raising the performance), while a drastically better informational architecture - via shortening the preparation times between the stages of production allows saving on the overhead, salaries and time to build too. The graph shown below is classified as «non-oriented, homogenous» in graph theory. 


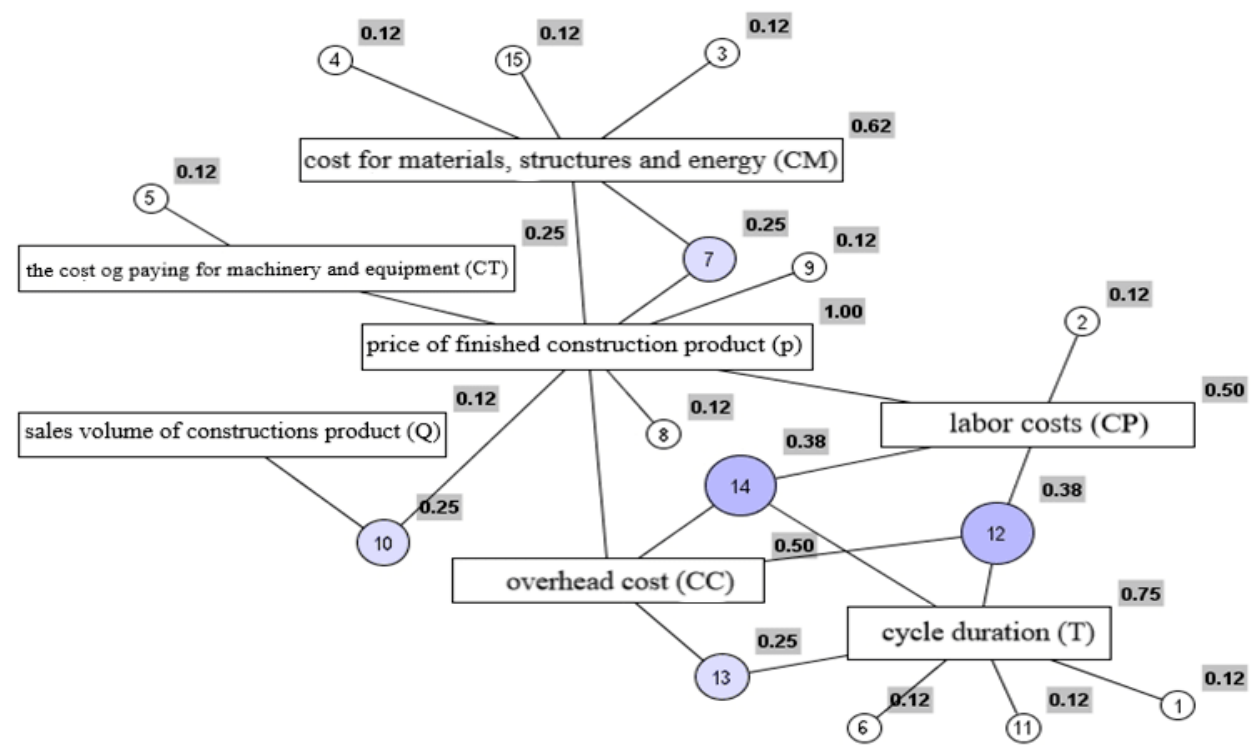

Fig. 1. The optimization graph of the production cycle in construction. Quantitatively, the median values of the corresponding variables for the NPV formula are shown.

The most important nodes are the cost of the product $(Q, 1.0-$ degree/value of the node), time to build $(t, 0.75)$, and expenditures $(C M, 0.62)$ (Fig. 1). All the nodes have at least one bond inside the graph, so the network is wholistic and emergent.

Symbol « $\Delta$ » shows the level of efficiency increase by the innovation.

Every single innovation leads to better results across all the nodes of the graph, like in a domino effect.

Our research had shown four challenges in front of the innovation in construction in Russia.

- Positive feedback loops, synergies, non-zero sum games are hard to understand intuitively and wholistically. If the effect of innovation is not vividly seen immediately, well before the end of the production cycle, there's usually not enough data to decide in favor of innovation. The more conservative, incremental, limited innovations lead to the adequately incremental increase in productivity (1-5\%) [17]. As the world's best practice shows, the complex solutions, solutions that change the product and the technology throughout the whole production cycle, are the most effective - by the measure of $12 \%$ and more [18]. Conclusion: division of the tendering process by stages is detrimental for the innovation in construction.

- Innovation and new technology aren't the same phenomenon. Non-technological innovation exists - and is just as crucial as technological innovation is. Very few people understand the existence and importance of non-technological innovation. Innovation is any divergent practice that adds value to your economic activity. In some edge cases, the added value can even be expressed only in non-economic terms. The lack of understanding those points leads to the innovation in building materials and other adjacent technologies are to be approved by the high command $[19,20]$. Innovative business models, social, marketing, and organizational innovations are the almost completely untapped opportunities for growth [21,22].

- The lack of a well-defined vision of the future leads to a lack of the understanding of how exactly the innovation will deliver the better outcomes and whether it's all worth it. 
It's hard to analyze and estimate the effects of innovation. The incorrect descriptions of the innovative products certainly don't help with changing people's minds about it. Some of the examples of the real incorrect claims provided by the manufacturers of the innovative products are: «the self-healing elastic concrete is lighter by $40-50 \%$ than the regular concrete», "we provide highly durable construction materials with a compressive strength not less than $200 \mathrm{MPa}$ (2000 bars)». There's no standard well-researched procedure for estimating the outcomes of innovation - which is essential for the commercialization of the R\&D results. There's not enough transparency and trust in sharing the info about the R\&D results. Managers believe that higher risk means less procurement. Monopolization of the market leads to there being no point in taking risks: for there can be no risk that will significantly affect any company's market share. The government's conservative approach to procurements is another big factor in slowing down the innovation.

- The legal challenges of dealing with the things that aren't particularly well-understood by the law yet. When it's mentioned in the «technical task» document that there's an innovative component to your product, the antitrust law officials see it as an opportunity to sue your company for the uncompetitive practices.

\section{Conclusion}

For the innovation to be enough of an upside risk that it can be approved by the investors, the innovation should affect the whole production cycle drastically, and not be a hyperlocal incremental innovation. Construction industry's unique experience with the analysis and methodology of innovation is useful and transferable to the other domains of knowledge where there's care about growth and innovation.

\section{Acknowledgments}

The authors of this article are sincerely grateful to the faculty members and organizers of the journal club called «Methodological problems of the economic effectiveness of regional construction clusters as a self-ordering system».

\section{References}

1. A. Platonov, V. Larionova, Y. Davy, S. Bazhenov, Theoretical and methodological approaches to management of resource flow processes of development projects on macro-, mezzo-, microlevels, IOP Conference Series: Materials Science and Engineering, 972(1), 012060 (2020) DOI:10.1088/1757-899X/972/1/012060

2. N. A. Polovnikova, N. V. Chepachenko, M. N. Yudenko, Study and evaluation of the competitiveness potential of the organizations in the construction industry, Materials Science Forum, 931 MSF, 1178-1181 (2018) DOI: 10.4028/www.scientific.net/MSF.931.1178

3. N. V. Chepachenko, A. A. Leontiev, G. A. Uraev, V. D. Ardzinov, Modeling the effect of using the innovative materials on the construction organizations economic performance, IOP Conference Series: Materials Science and Engineering, 698(7), 077038 (2019). DOI: 10.1088/1757-899X/698/7/077038

4. Aviad Shapira; Yehiel Rosenfeld, Achieving Construction Innovation through Academia-Industry Cooperation-Keys to Success, Journal of Professional Issues in Engineering Education \& Practice, 137, 4, 223-231 (2011) DOI: 10.1061/(ASCE)EI.1943-5541.0000057 
5. S. Ivanov, Structure of transactional costs of business entities in construction, World Applied Sciences Journal, 23(13), 80-83 (2013) DOI: 10.5829/idosi.wasj.2013.23.pac.90017

6. J. H. Rankin, , R. Luther, The innovation process: adoption of information and communication technology for the construction industry, Canadian Journal of Civil Engineering, 33, 12, 1538-1546 (2006) DOI: 10.1139/105-128

7. Marcela Miozzo, Paul Dewick, Networks and innovation in European construction: benefits from inter-organisational cooperation in a fragmented industry, International Journal of Technology Management, 27, 1, 68-89 (2004) DOI: 10.1504/IJTM.2004.003882

8. I. Artamonova, , B. Khrustalev, Increasing the innovative potential of the enterprise building complex, E3S Web of Conferences, 91, 08033 (2019) DOI: 10.1051/e3sconf/20199108033

9. G. Zagidullina, R. Ivanova, R. Sirazetdinov, I. Badykova, E. Biktemirova, Modeling of the innovative activity for the enterprises in investment based construction industry, IOP Conference Series: Materials Science and Engineering, 890(1), 012119 (2020) DOI: 10.1088/1757-899X/890/1/012119

10. A. I. Shinkevich, A. A. Lubnina, N. M. Chikisheva, R. S. Sadykova, R. R. Kharisova, Innovative forms of production organization in the context of high-tech Meso-economic systems sustainable development, International Review of Management and Marketing, 6(S2), 219-224 (2016).

11. R. Mavlioutov, M. Belyaev, K. Borisova, Reengineering of manufacturing processes in the construction organization, IOP Conference Series: Materials Science and Engineering, 890(1), 012120 (2020) DOI: 10.1088/1757-899X/890/1/012120

12. E. Aleksandrova, V. Vinogradova, G. Tokunova, Integration of digital technologies in the field of construction in the Russian Federation, Engineering Management in Production and Services, 11(3), 38-47 (2019) DOI: 10.2478/emj-2019-0019

13. G. Tokunova, M. Rajczyk, Smart technologies in development of urban agglomerations (case study of St. Petersburg transport infrastructure), Transportation Research Procedia, 50, 681-688 (2020). DOI: 10.1016/j.trpro.2020.10.080

14. M. Voynarenko, L. Yemchuk, L. Dzhulii, New realities of the enterprise management system information support: Economic and mathematical models and cloud technologies, Journal of Information Technology Management, 12(3) (2020) DOI: 10.22059/JITM.2020.76293

15. A. I. Romanova, D. S. Romanov, O. V. Maksimchuk, A. V. Voronin, Basic principles of innovation management in the urban economy of Smart-city, International Journal of Engineering and Technology (UAE), 7(4), 412-415 (2018) DOI: 10.14419/ijet.v7i4.38.24593

16. E. Pesotskaya, L. Selyutina, E. Trushkovskaya, Creation of integrated interaction monitoring in the construction companies management, IOP Conference Series: Materials Science and Engineering, 962(2), 022082 (2020) DOI: 10.1088/1757899X/962/2/022082

17. G. Zagidullina, R. Ivanova, G. Nugumanova, R. Sirazetdinov, A. Zaripova, The improvement of construction industry innovative potential through the creation of a cluster, IOP Conference Series: Materials Science and Engineering, 890(1), 012121 (2020). DOI: 10.1088/1757-899X/890/1/012121

18. D. Myers, Construction Economics: A New Approach (Taylor \& Francis, 2008).

19. M. N. Yudenko, N. V. Chepachenko, N. A. Polovnikova, S. A. Nikolikhina, Innovative materials in construction and their role in improving the organizations efficiency, IOP Conference Series: Materials Science and Engineering, 698(7), 077024 (2019) DOI: 10.1088/1757-899X/698/7/077024 
20. Y. A. Levin, A. A. Nikitin, M. V. Konotopov, L. A. Ivanov, The potential of nanotechnology: Issues of heat supply and heating of buildings, Nanotechnologies in Construction, 12(2), 89-93 (2020) DOI: 10.15828/2075-8545-2020-12-2-89-93

21. M. Voynarenko, L. Dzhulii, L. Skorobohata, O. Mykoliuk, The Latest Information Systems in the Enterprise Management and Trends in their Development, in proceedings of the 9th International Conference on Advanced Computer Information Technologies, ACIT 2019, 8779874 (2019) DOI: 10.1109/ACITT.2019.8779874

22. A. N. Asaul, M. P. Voynarenko, L. V. Skorobogata, Transformation of business capitalization model within the knowledge economy. Actual Problems of Economics, 161(11), 8-15 (2014) 